\title{
Inhibition of Herpes Simplex Virus-1 by the Modified Green Tea Polyphenol EGCG-Stearate
}

\author{
Shivani N. Patel, Sandra D. Adams, Lee H. Lee \\ Department of Biology, Montclair State University, Montclair, NJ, USA \\ Email: adamssa@montclair.edu
}

How to cite this paper: Patel, S.N., Adams, S.D. and Lee, L.H. (2018) Inhibition of Herpes Simplex Virus-1 by the Modified Green Tea Polyphenol EGCG-Stearate. Advances in Bioscience and Biotechnology, 9, 679-690.

https://doi.org/10.4236/abb.2018.912046

Received: November 20, 2018

Accepted: December 25, 2018

Published: December 28, 2018

Copyright $\odot 2018$ by authors and Scientific Research Publishing Inc. This work is licensed under the Creative Commons Attribution International License (CC BY 4.0).

http://creativecommons.org/licenses/by/4.0/

\section{(c) (i) Open Access}

\begin{abstract}
Epigallocatechin gallate (EGCG), a green tea polyphenol possesses antioxidant, antibacterial, anticancer and antiviral properties. EGCG-Stearate (EGCG-S) is of interest for this study because of its stability and lipophilic properties. The chemical modification of EGCG-S increased its lipid solubility. Herpes simplex virus-1 (HSV-1), a member of the family Herpesviridae, and Alphaherpesvirinae subfamily is a leading cause of human viral diseases in the United States. In this study, $25 \mu \mathrm{M}, 50 \mu \mathrm{M}, 75 \mu \mathrm{M}$, and $100 \mu \mathrm{M}$ of EGCG and EGCG-S were used to carry out cytotoxicity, cell viability and cell proliferation assays to determine the maximum non-cytotoxic concentrations on cultured A549 cells. The results suggested that $75 \mu \mathrm{M}$ of EGCG and EGCG-S is the appropriate concentration to further study the effect on the infection of HSV-1 in A549 cells. Infectivity, antiviral, and inverted microscopy assays were performed to study the effects of EGCG and EGCG-S on HSV-1 infection. An antiviral assay was performed using luminescence and it indicated that EGCG-S treated HSV-1 showed up to $90 \%$ inhibition. Confocal microscopy images further supported the inhibitory effects of $75 \mu \mathrm{M}$ EGCG-S on HSV-1 infection in A549 cells. The long-term goal of this research is to use EGCG-S as a possible novel topical therapeutic treatment to limit the spread of HSV-1 infections.
\end{abstract}

\section{Keywords}

HSV-1, EGCG-Stearate, EGCG, Antiviral, A549 Cells

\section{Introduction}

Herpes Simplex Virus-1 (HSV-1) is a member of the family Herpesviridae, and subfamily Alphaherpesvirinae. Herpesviruses are double-stranded, and enve- 
loped DNA viruses that cause a wide range of diseases in humans and other animals [1] [2]. The 152-kb linear genome of HSV-1 encodes $\sim 80$ genes; symptoms of HSV-1 infection include oral and genital cold sores, ocular sores, and encephalitis [2]. HSV-1 affects about $70 \%-80 \%$ of individuals in lower socioeconomic populations and about $40 \%-63 \%$ of individuals in upper socioeconomic population in the United States [3] [4]. HSV-1 undergoes both lytic and lysogenic infection cycles. HSV-1's infection cycle begins with a rapid lytic infection of epithelial cells (typically oral) in vivo and in susceptible cultured cells in vitro. HSV-1 is also neurotropic and infection proceeds into nearby neurons via retrograde axonal transport, ultimately resulting in life-long latency in host sensory neurons [5] [6] [7] [8] [9]. Since, the virus undergoes lysogenic infection, the immune system of an individual could never get rid of the virus completely. Therefore, recurrent viral infections are always a threat for HSV infected individuals.

Epigallocatechin-3-gallate (EGCG), a green tea polyphenol, is the primary catechin obtained from leaves of the Camellia sinensis plant. EGCG has been previously demonstrated to have antiviral properties against several viruses including HIV, hepatitis B, hepatitis C, influenza, adenovirus, and Zika [10]-[23]. EGCG has been shown to inhibit HSV-1 in Vero cells prior to virus adsorption [24]. However, EGCG is chemically unstable and sensitive to biological transformation reactions [25] [26]. Lipophilized EGCG exhibits greater antioxidant potential than EGCG. Additionally, esterification improves the stability of EGCG [27] [28]. Palmitate EGCG was found to be an effective inhibitor of porcine reproductive and respiratory syndrome virus (PRRSV) [29]. The fatty acid modified palmitoyl-EGCG (pEGCG) was found to inhibit adsorption of HSV-1 virions to Vero cells [30]. The structure of EGCG was modified by esterification to produce a lipophilized EGCG-acyl ester derivative containing stearic acid, also termed EGCG-Stearate (EGCG-S). Due to the enhanced solubility, EGCG-S is a more potent form that can be used in formulations to be applied in medicine [31] [32]. This form of EGCG may reduce the susceptibility to metabolic changes seen for the regular EGCG in clinical applications. EGCG-S, a more stable and lipid soluble derivative of EGCG is used in this study to investigate the effects of EGCG-S on HSV-1 infection in cultured A549 cells. The goal of this study is to assess the potential of EGCG-S to provide a novel therapeutic treatment to inhibit HSV-1 infections.

\section{Materials and Methods}

\subsection{Cell Culture}

A549 human epithelial [America Type Culture Collection (ATCC), Manassas, VA, USA] cells were cultured in T25 flasks using F12-K media supplemented with $10 \%$ Fetal Bovine Serum (FBS) and $1 \mu \mathrm{g} / \mathrm{mL}$ gentamicin. Trypsin EDTA $(0.25 \%)$ was used to subculture cells. The cells were maintained at $37^{\circ} \mathrm{C}$ and $5 \%$ $\mathrm{CO}_{2}$. 


\subsection{HSV-1 GFP}

A recombinant strain of HSV-1, GHSV-UL46, which contains the sequence for green fluorescent protein (GFP) fused to the tegument protein pUL46, was used for all experiments [33] (ATCC, Manassas, VA, USA). Virus was passaged in T25 flasks and A549 cells were allowed to reach complete cytopathic effect (CPE). The viral media containing virus was then collected, centrifuged, and the supernatant stored at $-80^{\circ} \mathrm{C}$.

\subsection{Preparation of Green Tea Polyphenols}

EGCG (>90\%) purchased from Pulimeidi Biotechnology Co., Ltd. (Hangzhou, China) and EGCG-S (US Patent 20120172423) modified by and purchased from Camellix, LLC, Augusta, GA, were dissolved in dimethyl sulfoxide (DMSO) and ethanol to prepare initial $5 \mathrm{mM}$ stock concentrations. EGCG and EGCG-S were then diluted in F12-K media to desired concentrations of 12.5, 25, 50, 75, and $100 \mu \mathrm{M}$.

\subsection{Alterations of Cell Morphology}

A549 cells were plated in 6 well plates, grown for 24 hours and treated with various concentrations $(25,50$, and $75 \mu \mathrm{M})$ of EGCG and EGCG-S. After 1 hour the EGCG and EGCG-S were removed by aspiration and the cells were washed with phosphate buffered saline (PBS). Media was then added to the wells and cells were incubated at $37^{\circ}$ under $5 \% \mathrm{CO}_{2}$ and observed every 24 hours for a period of three days after treatment. Cells were examined, using an inverted microscope, at $400 \times$ magnification to observe morphological changes in the cells.

\subsection{Cell Viability}

A549 cells were plated in 6 well plates and treated with appropriate concentrations of EGCG and EGCG-S for $1 \mathrm{hr}$. The viable cells were then stained and counted using trypan blue and hemocytometer. After $1 \mathrm{hr}$, the EGCG and EGCG-S were aspirated and the cells were washed with PBS. F12K media was then placed in each well and cells were incubated for $24 \mathrm{hrs}$. Cells, including controls of ethanol (ETOH) and DMSO, were trypsinized and harvested. Cells were then stained with trypan blue, which stains dead cells blue while live cells are not stained, and counted using a hemocytometer. Cell viability was determined by the proportion of viable cells to control levels at different treatments, and illustrated as relative cell viability with the controls as $100 \%$ viable.

Cell viability $(\%)=$ total viable cells (unstained)/total cells (stained and unstained) $\times 100$

\subsection{Cell Proliferation}

A549 cell suspensions $(100 \mu \mathrm{L})$ were plated in separate wells in a 96 well plate and after 24 hours cells were treated with appropriate concentrations of EGCG and EGCG-S for one hour, then aspirated (as described in section 2.5). After 24 
hours, $10 \mu \mathrm{L}$ of WST-1 reagent (Roche Diagnostics, Indianapolis, IN, USA) was then added to the samples; the plate was gently rocked, then incubated at $37^{\circ} \mathrm{C}$ under $5 \% \mathrm{CO}_{2}$ for 30 minutes. The absorbance level for each well of the plate was measured at $450 \mathrm{~nm}$ in a 96 well plate reader. The assay was performed in triplicate.

\subsection{Antiviral Assay Using Luminescence}

A549 cells were plated in a 96 well plate and after 24 hours, $100 \mu \mathrm{L}$ of virus was treated with $100 \mu \mathrm{L}$ EGCG-S (final concentrations are 25, 50, 75, and $100 \mu \mathrm{M}$ ) for one hour. After treatment, cells were infected with treated and non-treated virus and incubated for one hour at $37^{\circ} \mathrm{C}$ and $5 \% \mathrm{CO}_{2}$. Any unabsorbed virus was aspirated and replaced with $100 \mu \mathrm{L}$ of F12-K media. After 72 hours, $10 \mu \mathrm{L}$ of ToxGlo reagent (Promega, Madison, WI, USA) was added to all wells containing samples (controls included $100 \mu \mathrm{L}$ of $10 \%$ FBS-F12-K media both with and without the ToxGlo reagent) then incubated at $37^{\circ}$ and $5 \% \mathrm{CO}_{2}$ for 15 minutes. The plate was then read through a luminometer and relative light unit (RLU) values of each well were recorded. The assay was performed in triplicate.

The equation for calculating the percent of inhibition is shown below:

$\%$ inhibition $=[($ Cells + treated HSV1 $)-($ Cells + HSV1) $] /[$ Cells only $-($ Cells + HSV1)]

\subsection{Inverted Microscopic Observation}

A549 cells were plated in 6 well plates and were infected with $200 \mu \mathrm{L}$ of various dilutions of treated or non treated HSV-1 for one hour incubation, with intermittent rocking at $37^{\circ} \mathrm{C}$ and $5 \% \mathrm{CO}_{2}$. After one hour, unabsorbed virus was aspirated and $2.5 \mathrm{~mL}$ of media was added to each well and incubated at $37^{\circ} \mathrm{C}$ and $5 \% \mathrm{CO}_{2}$. Morphological changes were observed at day 3 post-infection.

\subsection{Confocal Microscopy}

A549 cells were grown on glass cover slips within 12 well plates and were infected with treated or non-treated virus for one hour. Twelve hours post infection, cells were stained with $300 \mu \mathrm{L}$ of $300 \mathrm{nM}$ DAPI (4,6-diamidino-2-phenylindole) stain for 5 minutes at $37^{\circ} \mathrm{C}$ in the dark. Cells were then fixed with polyethylene glycol solution for 15 minutes at $20^{\circ} \mathrm{C}$. The glass cover slip containing cells were then glued to a slide using a drop of clear nail polish. Cells were then visualized and were examined under a Leica SP5 scanning confocal microscope under $10 \times$ or $63 \times / 1.4$ NA water Plan Apo objectives at Vassar College (Poughkeepsie, NY).

\section{Results}

\subsection{Alterations of Cell Morphology}

To study the effect of ECGC and EGCG-S on A549 human epithelium cells, different concentrations $(25,50$ and $75 \mu \mathrm{M})$ of EGCG and EGCG-S were used. The 
morphology was observed at 24, 48 and 72 hours after the treatment as shown in Figure 1. There were no observed effects of dissolving in ethanol or DMSO; therefore, the study was continued using DMSO as the solvent. Since the polyphenols were dissolved in DMSO (the media contained < $2 \%$ DMSO in solution) the effect of DMSO was also studied. The results indicated that DMSO at these concentrations $(0.5 \%, 1 \%$, and $1.5 \%$, respectively) had no effect on cell morphology; DMSO treated cells did not appear different from the control cells (Figure 1(a) and Figure 1(b)). The alterations of cell morphology study demonstrated that tested concentrations of both EGCG and EGCG-S are not toxic to A549 cells. Concentrations of $25 \mu \mathrm{M}, 50 \mu \mathrm{M}$, and $75 \mu \mathrm{M}$ of EGCG and EGCG-S do not show any morphological changes and no cytopathic effects in growing A549 cells (Figure 1(c)). These results suggested that the cells can tolerate EGCG and EGCG-S at concentrations up to $75 \mu \mathrm{M}$.

\subsection{Cell Viability and Proliferation Assays}

The cell viability was determined using the Trypan blue assay. After treatment with Trypan blue, cells were counted using a hemocytometer. The percent (\%) of viability was calculated as explained in the Materials and Methods. The results are shown in Figure 2. It is indicated that ETOH and DMSO have no effect on

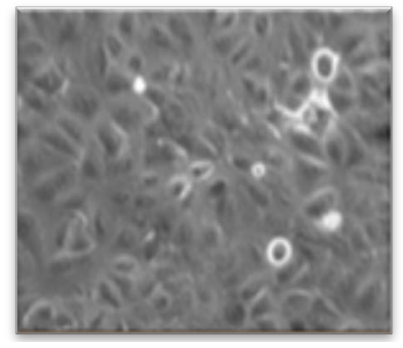

(a)

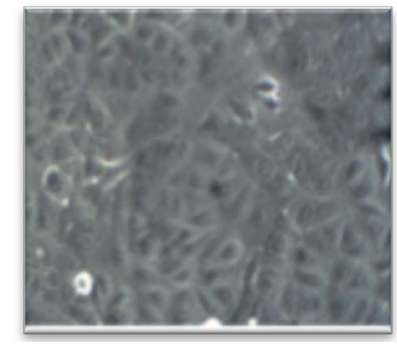

(b)

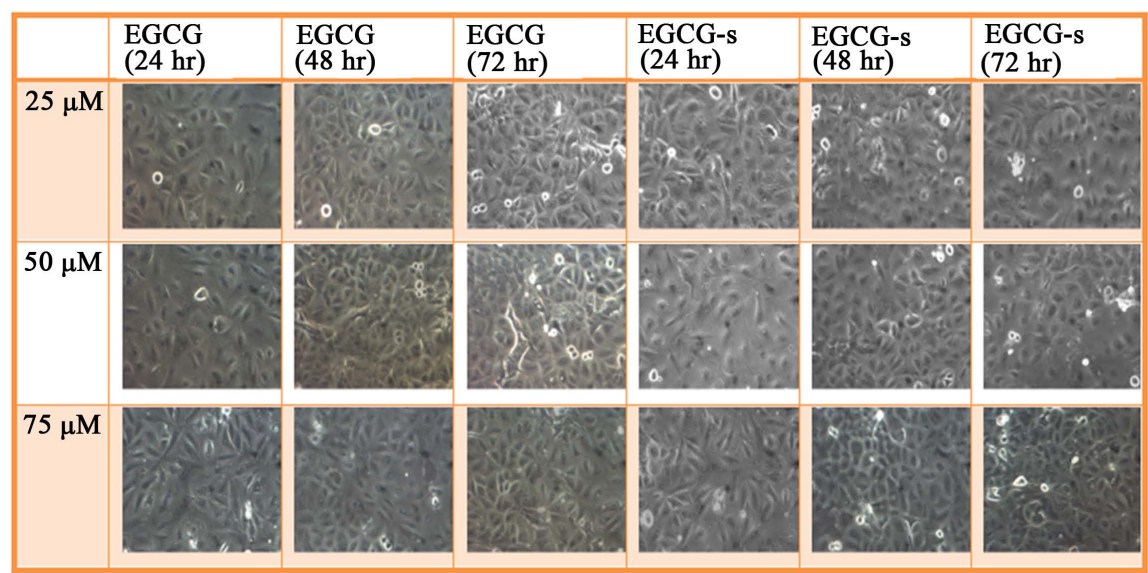

(c)

Figure 1. Microscopic observation (200x) of cell morphology indicating cytotoxicity of cells under different conditions (a) control, A549 cells only; (b) A549 cells treated with DMSO; (c) Cells in different concentrations of EGCG and EGCG-S (25, 50 and $75 \mu \mathrm{M})$ for 24,48 and 72 hours. 


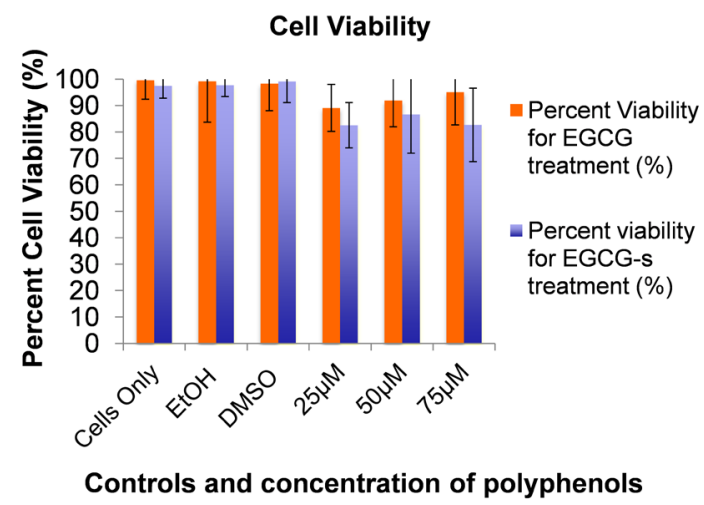

Figure 2. Cell Viability Assay of controls and A549 cells treated with EGCG or EGCG-S at concentrations of 25,50 , and $75 \mu \mathrm{M}$.

cell viability, with $\%$ viability of $98 \%$ and $100 \%$, respectively, when compared with the control. For EGCG the \% of viability ranges from $89 \%$ to $95 \%$; for EGCG-S, the $\%$ of viability ranges from $83 \%$ to $87 \%$. The cell proliferation assay using WST-1 was carried out to analyze the proliferation activity of cells. The results are shown in Figure 3. The data indicated that concentrations of 25, 50 and $75 \mu \mathrm{M}$ of EGCG and EGCG-S do not affect cell proliferation. These concentrations could be used to treat the HSV-1 virions and would not affect the cells. The cell viability assay indicates that there is a slight decrease in the number of viable cells with increasing concentrations of EGCG and EGCG-S. However, EGCG and EGCG-S do not show any effect on A549 cells and the cell proliferation assay confirms that EGCG and EGCG-S do not affect the growth of A549 cells at the concentrations tested.

\subsection{Antiviral Assay}

The ToxGlo antiviral assay was used to measure cell viability in infected cells in response to EGCG-S treatment of the virus. The calculated percentage of inhibition ranged from $\sim 80 \%$ at the highest concentration of EGCG-S while the maximum viral inhibition occurred at a concentration of $75 \mu \mathrm{M}$ (>90\%) (Figure 4). Antiviral assay using luminescence suggests that EGCG-S treatment inhibits HSV-1 by up to $90 \%$.

The equation for calculating the percent of inhibition is given in Section 2.7 of the materials and methods.

\subsection{Inverted Microscopic Observation}

A549 cells were plated in 6 well plates and were infected with treated and non treated HSV-1 for one hour. After an hour, unabsorbed virus was aspirated and media was added. Morphological changes were assessed at three days post-infection. The results are shown in Figure 5. The uninfected cells showed the typical flattened, elongated morphology characteristic of epithelial cells (Figure 5(a)). The cells infected with HSV-1 demonstrate properties of cytopathic effects; the cells are rounded and lifted from the monolayer (Figure 5(b)). 


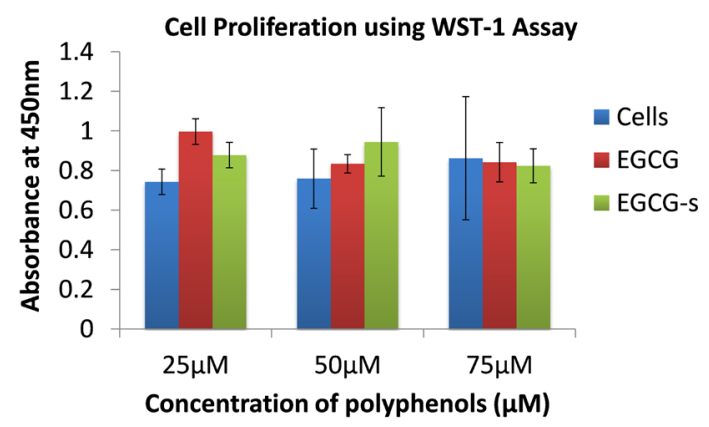

Figure 3. Cell proliferation assay of A549 cells and cells treated with 25, 50 and $75 \mu \mathrm{M}$ of EGCG or EGCG-S.

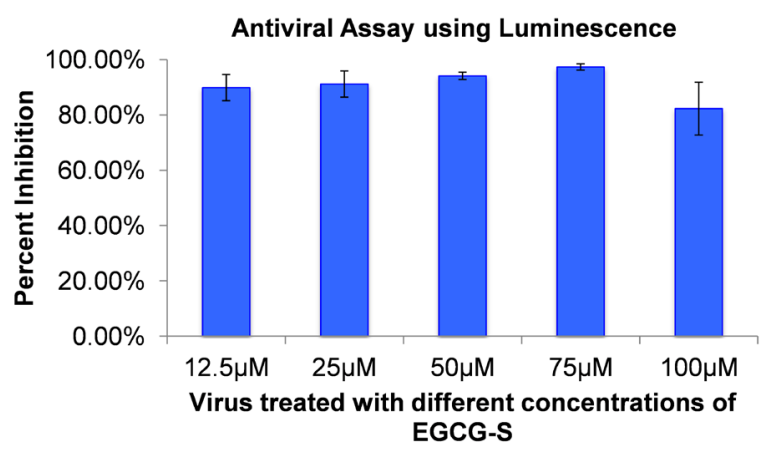

Figure 4. Antiviral assay using ToxGlo reagent in the presence of different concentrations of EGCG-S.

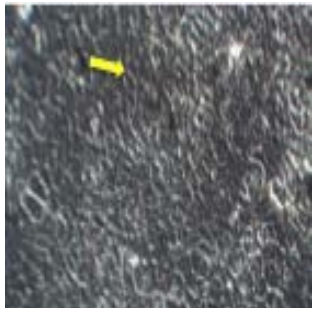

(a)

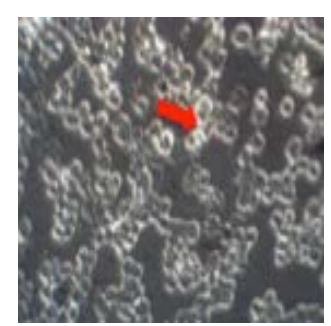

(b)

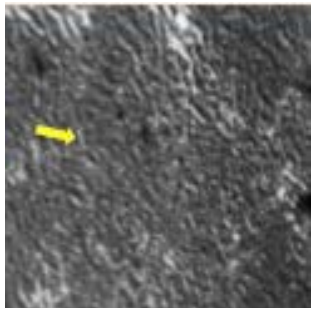

(c)

Figure 5. Inverted microscopic observation (200×) (a) A549 cells; (b) A549 cells infected with HSV-1 C. A549 cells infected with $75 \mu$ M EGCG-S treated HSV-1. The red arrow indicates rounding of cells and the yellow arrows indicate cell monolayer attached to the surface of the well.

HSV-1, treated with $75 \mu \mathrm{M}$ of EGCG-S, infected cells showed very similar cell morphology to the untreated control cells (c). This study suggests that $75 \mu \mathrm{M}$ of EGCG-S was able to inhibit HSV-1 infection in cultured A549 cells thus the cells' morphology remained similar to the morphology of the uninfected control.

\subsection{Confocal Microscopy}

HSV-1 used in this study contains the sequence for GFP fused to the sequence for the tegument protein, UL-46 [33]. GFP expression indicates a late stage in the HSV-1 replication cycle. DAPI stain was used to determine the morphology and number of cell nuclei. Figure 6(a) shows uninfected A549 cells. Figure 6(b) 


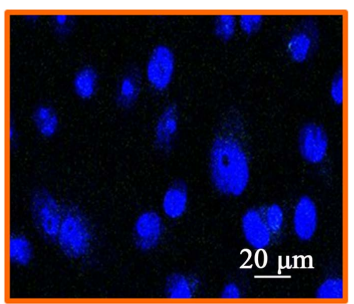

(a)

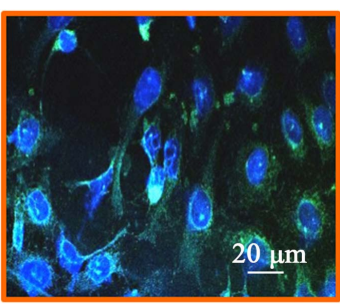

(b)

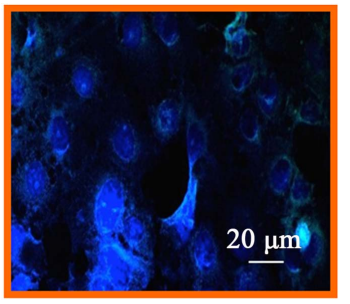

(c)

Figure 6. Confocal microscopic image (400x) of (a) uninfected A549 cells; (b) Confocal Microscopic image of 12 hour post infection observation of non treated HSV-1 in A549 cells; (c) Confocal Microscopic image of 12 hour post infection observation of $75 \mu \mathrm{M}$ EGCG-S treated HSV-1 in A549 cells.

indicates extensive HSV-1 infection. However, when HSV-1 is treated with 75 $\mu \mathrm{M}$ EGCG-S there is minimal GFP expression as shown in Figure 6(c). The confocal microscopy study suggests that $75 \mu \mathrm{M}$ EGCG-S treatment of HSV-1 results in a drastic reduction in GFP expression and hence, inhibition of HSV-1 when observed at 12 hours post infection.

\section{Discussion}

There is a need to develop a treatment for herpes virus infections. Several natural compounds have been investigated as potential therapies. These natural products include eucalyptus extracts [34], polysaccharides and diglycerides [35], curcumin [36], and polyphenols from tea [24] [30] [37] [38]. Tea is one of the most widely consumed beverages worldwide. Tea, rich in catechins, has demonstrated antioxidation properties. Catechins, such as EGCG, however are rapidly metabolized [39]. The application of EGCG as a therapeutic agent is limited because of the chemical instability and tendency for EGCG to undergo biological transformations [25] [26]. Stability was affected by $\mathrm{pH}$, temperature, and ionic strength [40]. However, lipophilisation can improve the stability of EGCG [27] [31] [32] and hence, bioavailabilty. Lipophilisation increased the solubility of EGCG in lipids.

Herpes simplex virus infections continue to affect a large percentage of the human population worldwide. There is no cure for HSV-1 infections and there remains a need to identify effective and affordable therapies to reduce the incidence. The current treatment for herpes infections is acyclovir and its derivatives. Acyclovir is stable for oral and topical application; however, HSV resistance to nucleoside analogues has been reported due to mutations in viral thymidine kinase or polymerase [41]. This study tested the effect of a lipophilic, modified form of EGCG, EGCG-S, to inhibit the infection of HSV-1 in cultured cells.

Our results indicate that EGCG and EGCG-S can be safely applied to cultured A549 cells at concentrations up to $75 \mu \mathrm{M}$. Inhibition was measured visually as well as quantitatively. The ability of EGCG-S to inhibit HSV-1 infection was measured by a variety of assays including WST-1 cell proliferation assay, ToxGlo 
antiviral assay, inverted and confocal microscopy. The results of these assays demonstrate the inhibitory effects of treatment of HSV-1 virions with EGCG-S. EGCG has been reported to interact directly with HSV virions to inhibit attachment [24] [42]. Lipophilic p-EGCG inhibited adsorption of HSV virions to cultured cells [30]. It is probable that EGCG-S also acts in this manner since our results indicate that treatment of virions with EGCG-S inhibits herpes infections. Our results report inhibition between $80 \%$ and $90 \%$ with $75 \mu \mathrm{M}$ concentration of EGCG-S. EGCG-S in synergy with acyclovir could be an effective antiviral treatment for HSV infections.

\section{Conclusion}

EGCG-S, a more stable and lipid soluble derivative of EGCG, does not affect cellular morphology; is not cytotoxic; and can inhibit the infection of HSV-1 in cultured cells. EGCG-S shows promise for use as a topical therapeutic treatment to limit the spread of HSV-1 infections.

\section{Acknowledgements}

This research was funded in part by the Science Honors Innovation Program (SHIP) at Montclair State University and by the Faculty Scholarship Program.

\section{Conflicts of Interest}

The authors declare no conflicts of interest.

\section{Authors' Contributions}

SDA and LHL designed the study. SDA supervised SP in the laboratory. SP, SDA and LHL drafted the manuscript. SP conducted all experiments. All authors read and approved the final manuscript.

\section{References}

[1] Roizman, B. (1993) The Family Herpesviridae. In: Roizman, B., Whitley R.J. and Lopez, C., Eds., The Human Herpesviruses, Raven Press, New York, 1-9.

[2] Roizman, R., Knipe, D.M. and Whitley R.J. (2007) Herpes Simplex Viruses, In: Knipe, D.M. and Howley, P.M., Eds., Fields Virology, Vol. 2, Lippincott Williams \& Wilkins, New York, NY, 2501-2601.

[3] Fatahzadeh, M. and Schwartz, R.A. (2007) Human Herpes Simplex Virus Infections: Epidemiology, Pathogenesis, Symptomatology, Diagnosis, and Management. Journal of the American Academy of Dermatology, 57, 737-763. https://doi.org/10.1016/j.jaad.2007.06.027

[4] Xu, F., Schillinger, J.A., Sternberg, M.R., et al. (2002) Seroprevalence and Coinfection with Herpes Simplex Virus Type 1 and Type 2 in the United States, 1988-1994. The Journal of Infectious Diseases, 185, 1019-1024. https://doi.org/10.1086/340041

[5] Cook, M.J., Bastone, V.B. and Stevens, J.B. (1974) Evidence That Most Neurons Harbor Latent Herpes Simplex Virus. Infection and Immunity, 9, 945-951.

[6] Deshmane, S.L. and Fraser, N.W. (1989) During Latency, Herpes Simplex Virus 
Type 1 DNA Is Associated with Nucleosomes in a Chromatin Structure. Journal of Virology, 63, 943-947.

[7] Stevens, J.G. (1975) Latent Herpes Simplex Virus and the Nervous System. Current Topics in Microbiology and Immunology, 70, 31-50.

https://doi.org/10.1007/978-3-642-66101-3_2

[8] Kramer, M.F., Cook, W.J., Roth, F.P., Zhu, J., Holman, H., Knipe, D.M. and Coen, D.M. (2003) Latent Herpes Simplex Virus Infection of Sensory Neurons Alters Neuronal Gene Expression. Journal of Virology, 77, 9533-9541. https://doi.org/10.1128/JVI.77.17.9533-9541.2003

[9] Li, S., Hattori T. and Kodama, E.N. (2011) Epigallocatechin Gallate Inhibits the HIV Reverse Transcription Step. Antiviral Chemistry \& Chemotherapy, 21, 239-243. https://doi.org/10.3851/IMP1774

[10] Hamza, A. and Zhan, C.G. (2006) How Can (-)-Epigallocatechin Gallate from Green tea Prevent HIV-1 Infection? Mechanistic Insight from Computational Modeling and the Implication for Rational Design of Anti-HIV Entry Inhibitors. The Journal of Physical Chemistry B, 110, 2910-2917. https://doi.org/10.1021/jp0550762

[11] Kawai, K., Tsuno, N.H., Kitayama, J., Okaji, Y., Yazawa, K., Asakage, M., Hori, N., Watanabe, T., Takahashi, K. and Nagawa, H. (2003) Epigallocatechin Gallate, the Main Component of Tea Polyphenol, Binds to CD4 and Interferes with gp120 Binding. Journal of Allergy Clinical Immunology, 112, 951-957. https://doi.org/10.1016/S0091-6749(03)02007-4

[12] Xu, J., Gu, W.Z., Li, C.Y., Xing, G.Z., Song, Y.H. and Zheng, W.M. (2016) Epigallocatechin Gallate Inhibits Hepatitis B Virus via Farnesoid X Receptor Alpha. Journal of Natural Medicines, 70, 584-591. https://doi.org/10.1007/s11418-016-0980-6

[13] Xu, J., Wang, J., Deng, F., Hu, Z.H. and Wang, H.L. (2008) Green Tea Extract and Its Major Component Epigallocatechin Gallate Inhibits Hepatitis B Virus in Vitro. Antiviral Research, 78, 242-249. https://doi.org/10.1016/j.antiviral.2007.11.011

[14] Huang H.C., Tao, M.H., Hung, T.M., Chen, J.C., Lin Z.J. and Huang, C. (2014) (-)-Epigallocatechin-3-Gallate Inhibits Entry of Hepatitis B Virus into Hepatocytes. Antiviral Research, 111, 100-111. https://doi.org/10.1016/j.antiviral.2014.09.009

[15] Ciesek, S., von Hahn, T., Colpitts, C.C., Schang, L.M., Friesland, M., Steinmann, J., Manns, M.P., Ott, M., Wedemeyer, H., Meuleman, P., et al. (2011) The Green Tea Polyphenol, Epigallocatechin-3-Gallate, Inhibits Hepatitis C Virus Entry. Hepatology, 54, 1947-1955. https://doi.org/10.1002/hep.24610

[16] Calland, N., Albecka, A., Belouzard, S., Wychowski, C., Duverlie, G., Descamps, V., Hober, D., Dubuisson, J., Rouillé, Y. and Séron, K. (2012) (-)-Epigallocatechin3-Gallate Is a New Inhibitor of Hepatitis C Virus Entry. Hepatology, 55, 720-729. https://doi.org/10.1002/hep.24803

[17] Chen, C., Qiu, H., Gong, J., Liu, Q., Xiao, H., Chen, X.W., Su, B.L. and Yang, R.G. (2012) (-)-Epigallocatechin-3-Gallate Inhibits the Replication Cycle of Hepatitis C Virus. Archives of Virology, 157, 1301-1312.

https://doi.org/10.1007/s00705-012-1304-0

[18] Calland, N., Sahuc, M.-E., Belouzard, S., Pène, V., Bonnafous, P., Mesalam, A.A., Deloison, G., Descamps, V., Sahpaz, S., Wychowki, C., Lambert, O., Brodin, P., Duverlie, G., Meuleman, P., Rosenberg, A.R., Dubuisson, J., Rouillé, Y. and Séron, K. (2015) Polyphenols Inhibit Hepatis C Virus Entry by a New Mechanism of Action. Journal of Virology, 89, 10053-10063. https://doi.org/10.1128/JVI.01473-15

[19] Wang, Y., Li, J., Wang, X., Peña, J.C., Li, K., Zhang, T. and Ho, W. (2016) Epigallocatechin-3-Gallate Enhances Hepatitis C Virus Double-Stranded RNA Interme- 
diates-Triggered Innate Immune Responses in Hepatocytes. Scientific Reports, 6, Article ID: 215955. https://doi.org/10.1038/srep21595

[20] Song, J.M., Lee, K.H. and Seong, B.L. (2005) Antiviral Effect of Catechins in Green Tea on Influenza Virus. Antiviral Research, 68, 66-74. https://doi.org/10.1016/j.antiviral.2005.06.010

[21] Kim, M., Shin, J.S., Kim. P., Jung, Y.S., Jeong, H.S., Hyun, J.K. and Lee, C.K. (2013) Inhibition of Influenza Virus Internalization by (-)-Epigallocatechin-3-Gallate. Antiviral Research, 100, 460-472. https://doi.org/10.1016/j.antiviral.2013.08.002

[22] Weber, J.M., Ruzindana-Umunyana, A., Imbeault, L. and Sircar, S. (2003) Inhibition of Adenovirus Infection and Adenein by Green Tea Catechins. Antiviral Research, 58, 167-173. https://doi.org/10.1016/S0166-3542(02)00212-7

[23] Carneiro, B.M., Batista, M.N., Braga, A.C.S., Nogueira, M.L. and Rahal, P. (2016) The Green Tea Molecule EGCG Inhibits Zika Virus Entry. Virology, 496, 215-218. https://doi.org/10.1016/j.virol.2016.06.012

[24] Isaacs, C.E., Wen, G.Y., Xu, W., Jia, J.H., Rohan, L., Corbo, C., Di Maggio, V., Jenkins Jr., E.C. and Hillier, S. (2008) Epigallocatechin Gallate Inactivates Clinical Isolates of Herpes Simplex Virus. Antimicrobial Agents and Chemotherapy, 52, 962-970. https://doi.org/10.1128/AAC.00825-07

[25] Zhu, Q.Y., Zhang, A.T.D., Huang, Y. and Chen, Z.-Y. (1997) Stability of Green Tea Catechins. Journal of Agricultural and Food Chemistry, 45, 4624-4628.

[26] Sang, S., Lambert, J.D., Ho, C.-T. and Yang, C.S. (2011) The Chemistry and Biotransformation of Tea Constituents. Pharmacological Research, 64, 87-99. https://doi.org/10.1016/j.phrs.2011.02.007

[27] Zhong, Y. and Shahidi, F. (2011) Lipophilized Epigallocatechin Gallate (EGCG) Derivatives as Novel Antioxidants. Journal of Agricultural Food Chemistry, 59, 6526-6533. https://doi.org/10.1021/jf201050j

[28] Zhong, Y. and Shahidi, F. (2012) Lipophilised Epigallocatechin Gallate (EGCG) Derivatives and Their Antioxidant Potential in Food and Biological Systems. Food Chemistry, 131, 22-30. https://doi.org/10.1016/j.foodchem.2011.07.089

[29] Zhao, C., Liu, S., Li, C., Yang, L. and Zu, Y. (2014) In Vitro Evaluation of the Antiviral Activity of the Synthetic Epigallocatechin Gallate Analog-Epigallocatechin Gallate (EGCG) Palmitate against Porcine Reproductive and Respiratory Syndrome Virus. Viruses, 6, 938-950. https://doi.org/10.3390/v6020938

[30] Oliveira, A., Adams, S.D., Lee, L.H., Murray, S.R., Hsu, S.D., Hammond, J.R., Dickinson, D., Chen, P. and Chu, T.-C. (2012) Inhibition of Herpes Simplex Virus Type 1 with the Modified Green Tea Polyphenol Palmitoyl-Epigallocatechin Gallate. Food and Chemical Toxicology, 52, 207-215. https://doi.org/10.1016/j.fct.2012.11.006

[31] Hsu, S. (2015) Compounds Derived from Epigallocatechin-3-Gallate (EGCG) as a Novel Approach to the Prevention of Viral Infections, Inflammation. Allergy Drug Targets, 14, 13-18. https://doi.org/10.2174/1871528114666151022150122

[32] Zhao, M., Jiang, J., Zheng, R., Pearl, H., Dickinson, D., Fu, B. and Hsu, S. (2013) A Proprietary Topical Preparation Containing EGCG-Stearate and Glycerin with Inhibitory Effects on Herpes Simplex Virus: Case Study. Inflammation and Allergy_Drug Targets, 11, 354-368.

[33] Willard, M. (2002) Rapid Directional Translocations in Virus Replication. Journal of Virology, 76, 5220-5232. https://doi.org/10.1128/JVI.76.10.5220-5232.2002

[34] Brezani, V., Lelakova, V., Hassan, S.T.S., Berchova-Bimova, K., Novy, P., Kloucek, 
P., Marsik, P., Dall'Acqua, S., Hosek, J. and Smejkal, K. (2018) Anti-Infectivity against Herpes Simplex Virus and Selected Microbes and Anti-Inflammatory Activities of Compounds Isolated from Eucalyptus globulus Labill. Viruses, 10, 360.

[35] Chen, L. and Huang, G. (2018) The Antiviral Activity of Polysaccharides and Their Derivatives. International Journal of Biological Macromolecules, 115, 77-82. https://doi.org/10.1016/j.ijbiomac.2018.04.056

[36] Flores, D.J., Lee, H.L. and Adams, S.D. (2016) Inhibition of Curcumin-Treated Herpes Simplex Virus 1 and 2 in Vero Cells. Advances in Microbiology, 6, 276-287. https://doi.org/10.4236/aim.2016.64027

[37] Cantatore, A., Randall, S.D., Traum, D. and Adams, S.D. (2013) Effect of Black Tea Extract on Herpes Simplex Virus-1 Infection of Cultured Cells. BMC Complementary and Alternative Medicine, 13, 139. https://doi.org/10.1186/1472-6882-13-139

[38] Oliveira, A., Prince, D., Lo, C.-Y., Lee, L.H. and Chu, T.-C. (2015) Antiviral Activity of Theaflavin Digallate against Herpes Simplex Virus Type 1. Antiviral Research, 118, 56-67. https://doi.org/10.1016/j.antiviral.2015.03.009

[39] Higdon, J.V. and Frei, B. (2003) Tea Catechins and Polyphenols: Health Effects, Metabolism, and Antioxidant Properties. Critical Reviews in Food Science and Nutrition, 43, 89-143. https://doi.org/10.1080/10408690390826464

[40] Proniuk, S., Liederer, B.M. and Blanchard, J. (2002) Preformulation Study of Epigallocatechin Gallate, a Promising Antioxidant for Topical Skin Cancer Prevention. Journal of Pharmacological Science, 91, 111-116. https://doi.org/10.1002/jps.10009

[41] Strasfeld, L. and Chou, S. (2010) Antiviral Drug Resistance: Mechanisms and Clinical Implications. Infectious Disease Clinics of North America, 24, 809-833. https://doi.org/10.1016/j.idc.2010.07.001

[42] Colpitts, C.C. and Schang, L.M. (2014) A Small Molecule Inhibits Virion Attachment to Heparan Sulfate- or Sialic Acid-Containing Glycans. Journal of Virology, 88, 7806-7817. https://doi.org/10.1128/JVI.00896-14 